\title{
EESTI KOOLIÕPILASTE LUGEMISHARJUMUSED
}

\author{
HELIN PUKSAND
}

$\mathrm{V}$

iimastel aastatel kostab õpetajate ja hariduselu pärast muretsejate suust üha sagedamini, et noored ei taha tänapäeval lugeda. Lugemise all peavad kurtjad silmas eelkõige ilukirjanduse lugemist, kuigi igapäevaselt loevad inimesed mitmel eesmärgil. Ka noored loevad uurimuste andmetel iga päev mitut liiki tekste, mis küll alati ei pruugi olla ilukirjandus.

Lugedes kulgeb ainuüksi arvuti taga üsna suur osa koolijärgsest päevast. Seal veedab umbes kolmveerand koolilapsi kaks kuni neli tundi ja enam. Pooled õpilastest loevad arvutis peale vahetu kirjaliku suhtluse veel tekste nii mõnest neid ennast huvitavast valdkonnast kui ka õppimise eesmärgil ja jälgivad uudiseid. Ajalehti loeb $80 \%$ ja ajakirju $72 \%$ teismelistest, mitmesuguseid aimeraamatuid aga kolmandik (vt Puksand 2010b, 2011). Samal ajal on üsna üldlevinud arvamus, et selline lugemine ei ole täisväärtuslik ning põhjustab noorte inimeste vaimset allakäiku. Seisukohta illustreerib majandusteadlane Andres Arraku (2012) arvamus, et „peale on kasvanud terve põlvkond tegelasi, kelle jaoks kolm lehekülge looduskirjeldust võrdub enesetapuga, kelle jaoks kümnete lehekülgede kaupa kultuurifilosoofiat „Dorian Gray portrees” jääb kättesaamatuks ja kes „Gilgameši” eepose asemel loeb lühikoomiksit”. Viimane oletus jääb õnneks tõest kaugele, sest koomikseid loeb noortest üldse vaid $13 \%$ (vt Puksand 2010a). Paljude kurtjate tõdemus jääbki aga oletuseks, sest vastavaid uuringuid ei ole nad läbi viinud ega lugenud. Priit Kruus (2010) arvab suisa, et selline murediskursus survestabki noori mitte lugema.

\section{Lugemine loeb}

Lugemine on muidugi oluline. Väärtfilm, kujutav kunst või muusika ei asenda inimese arengus üldiselt ilukirjandust. Näiteks arendab film kirjandusega sarnaselt küll noorte empaatiavõimet ja maailmapilti, kuid samas ei mõjuta ilukirjandusega võrdtugevasti kujutlusvõimet ega sõnavara ulatust: ettekujutuse tekstitagusest maailmast, nagu ka olustikku, inimesi, esemeid vm kirjeldava sõnavara asendab filmis pea täiesti visuaal. Ka jääb mujalt kättetulev sõnavara isiklike suhete ja individuaalse väärtusmaailma kontekstis väga kitsaks (kui mõelda nt ajakirjanduse ja koolisõnavara peale). Huvitavaid ja asjatundlikke arutlusi kirjanduse tähtsuse ja tähenduse üle leiab kooliinimene näiteks Varraku raamatublogist. ${ }^{1}$ Teaduslikult on teemat sügavuti käsitlenud kirjanduse ja filmi uurija David Miall (2006).

Ülemaailmses teismeliste uuringus on selgunud, et igapäevane, vältimatult vajalik lugemisosavus sõltub enim harjumusest lugeda mida tahes (Linnakylä 2008) - seda viimast nimetatakse lugemisosaduseks (ingl reading

1 Nt Krista Kaer „Brittide tubli lugemise edendamine” (30. V 2010), „Tõlkida või tõlkimata jätta” (19. VI 2010) või Märt Väljataga „Kirjand kohustuslikul teemal: „Tähesõjad” või „Väike Illimar”” (21. X 2011), „Populaarteadus kui tänapäeva filosoofia” (19. IX 2009). 
engagement). Et inimene end lugejana tajuks, ${ }^{2}$ peab lugemine olema talle loomuomane, sihipärane ja kujunema harjumuseks (ingl intrinsic, activityspecific, and habitual) (Garbe jt 2010: 27-31). Sealjuures ei eelda niisugune harjumus huvi ilukirjanduse vastu.

Eestis tegeldakse laste ja noorte lugemisharjumuste kujundamisega üsna palju ja sealjuures keskendutakse siiski just ilukirjandusele. Seda sihti toetavad muuhulgas mitmed Eesti Lugemisühingu projektid: eelkooliealisi ja algklassilapsi suunab raamatute juurde üle-eestiline „Lugemispesa” projekt, põhikooliõpilaste lugemisharjumusi kujundab aga arvutikeskkonna kaasabil projekt „Lugeda on mõnus”. Viimase oluline osa on laste ja noorte pidev arvamusvahetus ja muidugi õpetajate koostöö üle Eesti. ${ }^{3}$ Mõlemad projektid on pälvinud väga kõrge rahvusvahelise tunnustuse, Rahvusvahelise Lugemisühingu autasu Euroopa Innovaatiline Lugemisprojekt (esimene 2009 ja teine juba 2005). Eesti Lastekirjanduse Keskus korraldab iga kahe aasta tagant Nukitsa konkursi, kus lapsed ise valivad viimase kahe aasta parima raamatu ning selle põhjal selgitatakse välja populaarseim lastekirjanik ja lasteraamatukunstnik. Alates 1994. aastast tähistatakse 20. oktoobril Eesti Lastekirjanduse Keskuse algatusel ettelugemispäeva. Veebiotsing raamatute ettelugemine lastele annab üle 22000 vastuse; seda peavad aruteluteemade järgi oluliseks vanemad; selle tegevuse kaudu reklaamivad end lasteaiad ja isegi algkooli pikapäevarühmad. Ettelugemise üks vorme on unejuttude lugemine. Tiiu Tammemäe on oma doktoriväitekirjas välja toonud, et kaks kolmandikku eesti väikelastevanematest loeb unejuttu oma lapsele kas iga päev või paar korda nädalas; kõnearengu näitajad on nendel lastel, kellele unejuttu loetakse, oluliselt paremad kui neil lastel, kellele ette ei loeta (Tammemäe 2009: 81-82).

Seega võib näha, et lapsi suunatakse Eestis raamatute juurde juba maastmadalast ja selle nimel tehakse tööd, kuid samas ei ole piisavalt tegeldud lugemise mõiste muutmisega nii, et noored teadvustaks end lugejana ka siis, kui neil on vajadus ja harjumus lugeda pigem ajakirjandust, aime- ja tarbetekste, leida ja kontrollida teavet jne (vt Puksand 2010b). Asjatundjad (vt eespool viidatud teoseid) on veendunud, et enese tajumine lugejana tõstab igasugust, ka ilukirjanduse lugemise motivatsiooni, kuid see on omaette teema.

Mure ilukirjanduse vähese lugemise pärast on siiski õigustatud, seda näitavad mitmel moel noorte lugemisoskuse rahvusvahelise uurimuse PISA $2009^{4}$ tulemused. Näiteks oli Eesti 15-aastaste õpilaste keskmine tulemus funktsionaalses lugemises seal 501 punkti, millega Eesti on maailma 67 riigi

2 Lugemisterminoloogias räägitakse lugeja enesetajust või enese tajumisest lugejana, ingl self-concept as a reader.

3 Vt veebist Eesti Lugemisühing $\rightarrow$ Projektid.

4 PISA (Programme for International Student Assessment) on Majandusliku Koostöö ja Arengu Organisatsiooni (OECD) rahvusvaheline õpilaste hindamisprogramm, kus osaleb statistiliselt esinduslik valim riigi 15-aastasi õpilasi. Ülesanded on koostatud nii, et nende raskusastme järgi saaks kumuleeruvalt hinnata nende õpilaste osatähtsust, kes on teatud ülesanderühma abil mõõdetava lugemisosavuse saavutanud. Näiteks erandlikult osavaid 6. taseme lugejaid (saavutustase üle 708 punkti) oli Eestis 0,6\%; meisterlikke 5. ja 6. taseme lugejaid (626 või enam punkti) oli Eestis $6 \%$, 4. taseme omi (553 ja enam punkti) oli meil $27 \%$, 3. tasemel (vähemalt 481 punkti) oli Eestis $61 \%$ õpilasi. Väga hea tulemus on nõrkade lugejate väike määr: funktsionaalset õppimist igati toetava 2 . taseme lugemisoskuse saavutanute osatähtsuse poolest on Eesti oma 87 protsendiga Euroopas 2. kohal Soomes on nende protsent u 92 . Ôpetajate tähelepanu vajavad Eestis aga ülejäänud $13 \%$. 
hulgas 13. kohal ja statistiliselt 2. koha rühmas (punktide erinevus 10. ja 26. koha vahemikus ei ole statistiliselt oluline). Samal ajal oli ilukirjandust lugevate õpilaste keskmine tulemus 531 punkti ja nende laste tulemus, kes ilukirjandust ei loe, vaid 493 punkti. Summade vahe on 38 punkti ja 39punktiline erinevus tähendab PISA arvestuses juba terve õppeaasta jagu mahajäämust (vt Puksand 2010a).

Ilukirjanduse positiivsest mõjust lugemisosavusele räägib PISA 2009. aasta taustauuring (vt Puksand 2012b). Selles on selgunud, et tulemused on keskmisest paremad nendel lastel, kellel on kodus klassikalist kirjandust ja luulet - vastavalt 516 ja 511 punkti (vt Puksand 2012b). Ilukirjanduse ja lugemisosavuse vastastikust seotust näitavad ka teised samas arvutatud korrelatsioonid. Eesti noorte puhul ilmneb kõige tugevam sõltuvus ilukirjanduslugemuse ja saavutatud lugemistulemuse vahel, ${ }^{5}$ ja nii on see ka muudes maades ning teiste uurimuste järgi (vt nt Perie jt 2005). Muu lugemismaterjali ja lugemistulemuse vastastikune sõltuvus on meil väga väike. ${ }^{6}$ Arvutitekstidest on lugemisoskuse tasemega kõige tugevamini (aga mitte tugevasti) seotud veebientsüklopeediate ja -sõnastike kasutamine. ${ }^{7}$

Samas jääb õhku küsimus, mis on põhjus, mis tagajärg: kas ilukirjandust lugevate laste funktsionaalse lugemise oskus on hea seetõttu, et nad ilukirjandust loevad, või valib hea lugemisoskusega noor ülejäänutest meelsamini ka ilukirjandustekste, mis on enamasti ju suhteliselt mahukamad kui argine lugemisvara. Nii tekstiuurijad (nt Beaugrande, Dressler 1981) kui ka õpiteoreetikud (nt Schunk jt 2009: 211) on küll väitnud, et peamine õpi- ja lugemismotiiv on huvi, kuid samas selgub, et lugemistehnilised raskused ja teksti kiirus $^{8}$ pärsivad huvi kiiresti (Griffith, Ruan 2005: 9; vt ka Puksand, Kerge 2012: 191). Kui kaua on aga küsimus teksti (tehnilises) raskuses, see on terve omaette uurimisteema. Hiljutiste uurimuste järgi on teksti tihedus üsna sarnane näiteks noorte enda meilides ja romaanižanris, samal ajal kui kooliõpikute tekst on üle kahe korra tihedam (vt Puksand, Kerge 2012). Võib siis järeldada, et tähtsaim tegur on ikka motivatsioon.

\section{Ilukirjandus - kas ja mida?}

Tuleb tõdeda, et ehkki lugemist üleüldiselt naudib PISA küsitluse järgi $61 \%$ Eesti noortest, loeb ilukirjandust meelsasti vaid veerand 15-aastastest õpilastest (vt Puksand 2010a). Kuigi ülal viidatud jm uuringutest üle maailma nähtub, et teismelistel on teiselaadne rikas ja mitmepalgeline kirjaoskuskogemus ja -taust, mida pedagoogid sageli ei tunne ega kasuta (vt Considine jt 2009), on siiski huvitav teada, kas ja mida eesti emakeelega noored ilukirjanduse poolelt loevad.

5 Eesti 15-aastaste lugemisoskuse taseme ja ilukirjanduslugemuse korrelatsiooni $\mathrm{Q}=$ 0,282 (vt Puksand 2012b) peetakse massiivsetes sotsiaaluurimustes juba arvestatavaks.

6 Näiteks on korrelatsioon ajakirjade lugemise ja PISA lugemistulemuse vahel vaid 0,079 .

$7 \mathrm{Q}=0,187$.

8 Meriel Bloor jagab tekstid mõtte kulgemise järgi kiireteks ja aeglasteks (fast text versus slow text), kusjuures kiired tekstid eeldavad lugejalt asjatundmist ja meetoditega kursisolekut ega paku näiteid. Mida pikemad laused ja väiksem leksikaalne tihedus, seda aeglasema kuluga on tekst (Bloor 2004: 90-96). 
Saamaks teada, kas ja kui palju meie noored ilukirjandust loevad, viis siinkirjutaja 2008. ja 2009. aastal 9. ja 11. klassi õpilaste seas läbi laiaulatusliku uuringu. Uuringus osales 914 õpilast 17 eesti õppekeelega koolist üle Eesti. Uuritavate seas oli 497 tüdrukut ja 417 poissi (seega väike tüdrukute ülekaal), 479 õpilast oli 9 . klassist ja 435 õpilast 11. klassist. Tulemustest selgus, et $93 \%$ õpilastest oli uurimuse aastal lugenud ilukirjandust õpetaja nõudel ja $54 \%$ omal vabal valikul. ${ }^{9}$ Allpool nähtub ühtlasi, et erinevused põhikooli lõpuklassi ja gümnasistide vahel ei ole kuigi suured. Seega ei saa väita, et eesti noored ilukirjandust ei loe.

Lugemismotivatsiooni mõjutab tuntavalt õpilase huvi (vt eespool), mistõttu on oluline teada, missugused raamatud noortele meeldivad. Eelmainitud uurimuses, vastates küsimusele „Nimeta ilukirjandusteoseid (või autoreid), mis on sulle eriti meeldinud; põhjenda lühidalt, miks", tõi iga vastaja avatud loendina välja endale meeldinud ilukirjandusteosed ning põhjendas oma arvamust. Ôpilased nimetasid kokku 453 erinevat raamatut ja neist kattus vaid kolmandik: 160 raamatut märgiti ära rohkem kui üks kord. Paljud uurimused (vt OECD 2010: 73) on näidanud, et tüdrukud loevad ilukirjandust rohkem, ja see tendents tuleb ka siin välja - poisid on raamatuid nimetanud kolmandiku võrra vähem (206 raamatut tüdrukute 337 vastu). Kui võrrelda vastuseid klassiti, siis erinevus klasside vahel on üsna väike: 9. klassi õpilased on nimetanud 274 teost ja 11. klassi õpilased 287.

Eesti 9. ja 11. klassi õpilastele kõige enam meeldinud raamatud on J. K. Rowlingu Harry Potteri sari (67 vastajat), A. H. Tammsaare „Tõde ja õigus” (44), A. Kivirähki „Rehepapp” (41), A. Valliku Anni sari (40), J. R. R. Tolkieni „Sõrmuste isanda” triloogia + „Kääbik” (34), A. Kivirähki „Mees, kes teadis ussisõnu” (34), S. Henno „Mina olin siin” (34), E. M. Remarque’i „Läänerindel muutuseta” (30), Ch. Brontë „Jane Eyre” (23), D. Browni „Da Vinci kood” (22) ja F. Dostojevski „Kuritöö ja karistus” (22). Eelistustes on oluline ka lugeja sugu. Eeltoodud raamatutest on selgelt tüdrukute eelistuseks Anni sari (39 tüdrukut ja 1 poiss) ja „Jane Eyre” (kõik 23 tüdrukud); poisid olid ülekaalus „Sõrmuste isanda” triloogia puhul - selle raamatu tõi oma eelistusena välja 26 poissi ja 8 tüdrukut. Seda, kuivõrd esitatud lemmikteoste nimekiri kajastab ainult hetkeseisu, näitavad erinevatel aastatel tehtud uurimused (vt altpoolt). 453 raamatu hulgas on näiteks nimetatud ka praegu kuuldavasti väga populaarset raamatusarja „Videvik”, kuid esikümnesse see 2008.-2009. aastal ei jõudnud (vaid 6 nimetamist).

Põhikooli lõpuklassis ja gümnaasiumis lemmikraamatud ei kattu, kuid erinevus näib sõltuvat pigem kohustusliku kirjanduse iseloomust kui vabast valikust. 9. klassi õpilastele meeldivad kõige enam „Harry Potteri” sari (32), A. Valliku Anni sari (29), „Rehepapp” (28), „Mees, kes teadis ussisõnu” (20), „Mina olin siin” (19), „Sõrmuste isanda” triloogia + „Kääbik” (14), S. Henno „Elu algab täna” (12), „Da Vinci kood” (11), „Kuristik rukkis” (11) ja „Nimed marmortahvlil” (10). 11. klassi noorte lemmikraamatute esikümnesse kuuluvad aga „Tõde ja õigus” (43), „Harry Potteri” sari (35), „Läänerindel muutuseta” (23), „Kuritöö ja karistus” (22), „Dorian Gray portree” (20), „Sõrmuste isand” + „Kääbik” (20), „Jane Eyre” (16), „Mina olin siin” (15), „Mees, kes teadis ussisõnu” (14) ja „Rehepapp” (13). Nagu näha, kattub kahe vanuserühma

9 Tulemusi on illustreerivalt kasutatud 2011. a kehtima hakanud riiklikku põhikooli õppekava toetavas õpetajaraamatus (vt Puksand 2012a). 
lemmikute esikümnes neli raamatut ning ülejäänustki ulatub enamik üldisesse edetabelisse. Vaid „Nimesid marmortahvlil” on nimetanud ainult 9. ning „Kuritööd ja karistust” ainult 11. klass. Koolikirjanduse meeldivus tuleb eriti selgelt esile just gümnaasiumiõpilaste vastustes: „Tõde ja õigus”, „Läänerindel muutuseta”, „Kuritöö ja karistus” ning „Dorian Gray portree” on aastaid olnud kohustuslikud.

234 teismelist (102 poissi ja 132 tüdrukut) nimetas meelisraamatu asemel kirjaniku, kes on neile eriti meeldinud. Kokku nimetati kindlat teost esile toomata 83 autorit; 33 autorit märgiti ära rohkem kui üks kord. Kõige populaarsemaks osutus Andrus Kivirähk (20 nimetamist), talle järgnesid A. H. Tammsaare (12), Agatha Christie ja Terry Pratchett (11), Paulo Coelho (10), Dan Brown, E. M. Remarque (9), J. K. Rowling ja Fr. Tuglas (8), A. Lindgren, E. Hemingway ja S. Henno (7), J. R. R. Tolkien ja Kerttu Rakke (6), H. de Balzac ja K. Vonnegut (5).

Lemmikautoreid nimetavad 11. klassi õpilased oluliselt rohkem kui 9. klassi õpilased: vastavalt 64 ja 39. 9. klassis on lemmikud nt Kivirähk (10), Christie (5), Rowling (4) ning Lindgren, Hemingway, García Márquez, Ristikivi, Vonnegut, Henno ja Pratchett (kõiki nimetati 3 korda). 11. klassis nimetatakse lemmikutena järgmisi kirjanikke: Tammsaare ja Kivirähk (10), Coelho (9), Remarque (8), Brown (7), Christie, Pratchett ja Tuglas (6), Balzac (5), Lindgren, Hemingway, Rowling, Rakke ja Henno (4). Nagu näha, on ka siin kattuvusi.

Tegevõpetajatele ja õppekava koostajatele osutab uuema kirjanduse populaarsus kirjeldatud uurimuses seda, et kooli kohustuslikku kirjavarasse võiks aeg-ajalt lisada värskelt ilmunud kirjandust ja jätta kavasse ruumi individuaalseks valikuks.

Huvitavat võrdlust pakuvad ka varasemad uurimused. Näiteks on Bärbel Luhari ja Ester Sõrmuse järgi (2001) ka kümme aastat varem gümnaasiumiõpilaste lemmikteoste hulgas olnud „Jane Eyre”, „Tõde ja õigus”, „Läänerindel muutuseta” ning „Kuritöö ja karistus”. Kolm viimast on olnud mõlema uuringu ajal kohustusliku kirjanduse nimekirjas, mistõttu õpilane on nad avanud välisel sunnil. Näiteks põhjendab minu uuringus osalenud tütarlaps raamatu „Tõde ja õigus” valikut sõnadega: kui poleks seda teost kohustuslikus kirjanduses olnud, poleks ma seda eales kätte võtnud. Samas on tema ja paljud teised lugedes avastanud, et tegemist on huvitava teosega. Nii pole varasemad oletused tingimata õigeks osutunud: näiteks Malle Järve avaldas juba ligi 20 aasta eest arvamust, et Tammsaare „Tõe ja õiguse” populaarsus on hakanud kahanema (Järve 1993), kuid see teos on ka aastatel 2008-2009 õpilaste lemmikraamatute nimekirjas, olgu selle taga siis eesti kultuuri olulise tüviteksti igikestvus või ka käsitlusviiside kaasajastumine. „Jane Eyre” on aga tüdrukute lemmik olnud kogu siinkirjutajale adutava aja, kui mitte raamatu ilmumisest alates (1847, e.k 1959).

Ka Tartu Linnaraamatukogu laenutusedetabelitest võib leida samu raamatuid, mida uuringus nimetati: nii 2010. kui ka 2011. aasta eesti ilukirjanduse edetabelit juhivad „Tõde ja õigus”, „Rehepapp” ja „Kuidas elad, Ann?”; tõlkeilukirjanduses on mõlemal aastal kolmandal kohal „Läänerindel muutuseta" (Tartu Linnaraamatukogu kirjandusveeb s. a.). Kuna need raamatud on ka koolides kohustuslik kirjandus, siis on nad edetabelite tippu jõudnud arvatavasti just sel põhjusel. Teisalt näitab uurimuse kvalitatiivne analüüs (nagu 
ülalgi mainitud), et kohustuslikkuse tõttu leitakse kirjandusest sageli üles see väärtuslik, mis muidu parimas lugemiseas leidmata jääks.

Kui võrrelda lemmikraamatute ja -autorite nimekirja enim müüdud raamatute loendiga, mida koostab Eesti Kirjastuste Liit, siis võime kohata taas samu nimesid: 2005. aastal oli enim müüdud J. K. Rowlingu „Harry Potter ja segavereline prints” (13 372 eks); 2007. aastal oli ilukirjandusmenuk A. Kivirähki „Mees, kes teadis ussisõnu” (24 000 eks) ja lastekirjanduse valdkonna lemmik J. K. Rowlingu „Harry Potter ja surma vägised” (15 557). Ilmselt on nende raamatute ostunumbreid mõjutanud asjaolu, et Rowlingu kõnealused raamatud kuulusid juba populaarsuse võitnud sarja ja Kivirähk oli end Eesti kirjandusmaastikul tõestanud huvitava ja humoorika autorina. Teisalt, kui raamat on noorel kohe riiulilt võtta, siis on ilmselt suurem tõenäosus, et ta seda ka lugema hakkab. Näiteks on PISA taustauuringutes ilmnenud seos kodu kultuuritaseme (peamiselt klassikakirjanduse olemasolu) ja õpilase lugemistulemuse vahel (Välijärvi, Linnakylä 2002: 99-100). PISA 2009 taustauurimuse järgi meeldib ligi 30 protsendile eesti noortest raamatuid vahetada, 41 protsendile meeldib, kui neile raamatuid kingitakse, ning niisama paljudele meeldib käia raamatupoodides ja raamatukogudes. Enamik (ligi $80 \%$ ) noori armastab raamatute üle ka arutleda (vt Puksand 2010a: 65-67).

Koolinoortele meeldivad 2008.-2009. aasta uuringu avatud vastuste järgi eelkõige raamatud, mis on fantaasiaküllased (nt Harry Potteri sari, „Sõrmuste isanda" triloogia), kaasahaaravad ja seiklusrikkad (lisaks eelnimetatutele „Da Vinci kood”). Muuhulgas teevad raamatu noorte sõnul meeldivaks huumor (Kivirähki raamatud) ja lugeja eakaaslastest tegelased (Anni lood, „Mina olin siin”). Põhjenduste hulgast ei puudu ka filosoofiline ja sügavmõtteline sisu („Kuritöö ja karistus”, „Dorian Gray portree”). Eesti noored peavad teatud teoseid eesti kultuuris oluliseks („Tõde ja õigus”, Kivirähki raamatud). Mitmel korral, näiteks J. K. Rowlingu, A. Kivirähki, S. Henno, J. R. R. Tolkieni puhul, on vastajad lihtsalt rõhutanud, et autor (ja seega ka tema teos) meeldib.

Eesti noorte raamatueelistuste põhjused ei erine sellest, mida on leitud mujal. Näiteks on Rosemary Hopper (2005) välja toonud peamised põhjused, miks varateismelised ühe või teise raamatu valivad: 1) esmased teadmised raamatust või autorist, nt ollakse varem sama autori teoseid lugenud; 2) raamatu välimus - kaanekujundus, pildid, kirjasuurus; 3) kellegi soovitus - peamiselt loetakse pereliikmete või sõprade mõjul; 4) film või telesaade, nt Harry Potteri või „Sõrmuste isanda” filmid on toonud palju teismelisi alusteoste juurde; 5) žanr - osa lugejaid eelistab fantaasiajutte, teised tõsielulugusid. Kattuvusi leiab eesti noorte põhjendustest pea kõiges peale ladumistehniliste seikade. Et Eestis uuriti veidi vanemat earühma, lisanduvad positiivne hoiak autori suhtes, isiklik suhe teosega ja piisav vaimne pingutus.

Küsimuse „Kas oskad nimetada ka selliseid ilukirjandusteoseid (või autoreid), mis on sulle eriti vastumeelt olnud? Mis põhjusel?” vastustes toodi välja oluliselt vähem raamatuid, vaid 141 erinevat teost, poisid nimetasid neid 64 ja tüdrukud 116. Ebameeldivate raamatute eesotsas on eranditult kohustusliku kirjanduse teosed: V. Hugo „Jumalaema kirik Pariisis” (27 vastajat), E. Vilde „Mäeküla piimamees” (20), A. H. Tammsaare „Tõde ja õigus” (20), H. de Balzaci „Isa Goriot” (19), M. Undi „Hüvasti, kollane kass” (17), E. Hemingway „Vanamees ja meri” (17), E. Bornhöhe „Tasuja” (16), E. Kippeli 
„Meelis” (15), J. W. Goethe „Faust” (14), F. Dostojevski „Kuritöö ja karistus” (13), A. Puškini „Jevgeni Onegin” (13), Sophoklese „Kuningas Oidipus” (13), A. H. Tammsaare „Kõrboja peremees” (12), J. Krossi „Wikmani poisid” (11), H. Jõgisalu „Maaleib” (10), J. K. Rowlingu „Harry Potter” (9), E. Vilde „Mahtra sõda” (8), F. Dostojevski „Idioot”, A. Kitzbergi „Libahunt”, Stendhali „Punane ja must” (7), J. Joyce’i „Kunstniku noorpõlveportree” ja E. M. Remarque’i „Läänerindel muutuseta” (6), A. Kivirähki „Rehepapp” (5). Selle kõrval on mitu õpilast toonud eraldi välja, et ükski kohustuslik raamat ei meeldi ja kõik nad on igavad. Kui võrrelda mittemeeldinud raamatute nimekirja meeldinud raamatutega, siis võib näha, et „Tõde ja õigus” ning „Kuritöö ja karistus” esinevad mõlemas nimekirjas. Tegemist on mahukate ja keeruliste raamatutega, mis ilmselt pakuvad pinget vilunumale lugejale, kuid millega tehniliselt nõrk ja vaimse pingutusega harjumata lugeja (sh keskendumisraskustega noor ${ }^{10}$ ) võib tõeliselt hätta jääda. Samuti näeme mõlemas nimekirjas Harry Potteri sarja, raamatuid „Läänerindel muutuseta” ja „Rehepapp”. Tegelikult leiab peaaegu kõik õpilastele mittemeeldinud raamatud ka meeldinud raamatute nimekirjast. Õpetaja saab praeguseid õppekavu arvestades oma soovitusi suuresti kohandada ja siinkohal näib uurimus suunavat just kasutama enamaid valikuvõimalusi (seda enam, et üsna ilmselt ei sarnane ka osa nooremate õpetajate lugemus tingimata enam õpetajate vanema põlvkonna omaga).

Kirjandusinimesed omakorda võiksid eeltoodud nimekirja professionaalselt mõtestada. Õpilased väidavad eelkõige, et raamatud, mis ei meeldi, on igavad - nii iseloomustati peaaegu kõiki ebameeldivana nimetatud raamatuid. Veel ilmneb vastustest, et noortele ei meeldi tänapäeval pikad kirjeldused (nimetatud „Jumalaema kiriku Pariisis”, „Tõe ja õiguse” ning „Vanamehe ja mere" kontekstis). Samuti lubab uurimus järeldada, et raamatu võib ebameeldivaks muuta õpetaja ebahuvitav või õpilase aspektist vale käsitlus. Näiteks Mati Undi omaaegse kultusteose „Hüvasti, kollane kass” tõid mittemeeldinud raamatuna esile ainult ühe kindla klassi õpilased. Sarnane lugu oli Harri Jõgisalu raamatuga „Maaleib”, mis oli ühele klassile tehtud kohustuslikuks 4. klassis (need, kes seda teost ei lugenud, ei saanud ekskursioonile) veel 9. klassis mäletavad need õpilased seda kui igavat ja ebameeldivat raamatut. Seega võib arvata, et igal juhul jätab õpilasele negatiivse mälestuse raamat, mis pole talle ea- ega jõukohane.

Eelnevast kasvab välja küsimus, kas kirjandust tasub üldse kohustuslikuks teha. Ühest küljest peetakse Eestis loomulikuks, et meie lapsed loevad eesti ja maailmakirjanduse tüviteoseid ning peamine tee klassika juurde on koolikirjandus. Nii mitmelgi rahvusvahelisel konverentsil on imestatud, kas tõesti eesti lapsed loevad koolis Dostojevskit, mis meie jaoks on täiesti elementaarne. Tiit Hennoste rõhutab, et ühine loetud kirjandus on aidanud „luua inimestel endale ajalugu ja juured”. Ta arvab, et klassikalise ilukirjanduse lugemise vähenemisega võib kaduda oluline side, mis Eesti ühiskonda on koos hoidnud (Hennoste 2011). Kirjandusklassika tähtsuse toob välja ka Andres Arrak (2012): „Kui maailmaklassika varasalv on lugemata, jääb omandamata sõnavara. Kui ei ole sõnu, ei ole ka mõtteid." Teiselt poolt on koolikirjanduse valikute seas tegelikult väga väike osa suurepäraseid eesti keeles kättesaadavaid teoseid ning nii „oleme [kohustusliku kirjandusega - H. P.]

10 PISA 2009 taustauuringust selgus ka tõsiasi, et $17 \%$ õpilastest ei suuda paigal istuda ja lugeda rohkem kui paar minutit (vt Puksand 2012b). 
peaaegu surmale määranud uskumatu hulga tõlgitud ja tõlgitavat, kirjutatud ja kirjutamisel väärtvara" (Kerge 2003). Samuti räägib kohustusliku kirjanduse vastu tõik, et hoolimata sadadest väärtteostest kodudes ei kõneta paljud raamatud enam tänapäeva noort. Lugemisuurijad on näiteks veendunud, et just õigus eakohaselt ja individuaalselt oma lugemisvara kavandada loob eelduse igat laadi lugemisosaduse tekkeks (Sulkunen, Arffman 2010). Liivia Rebane toob oma magistritöös välja, et vaid kolmandik uuritud kolmanda kooliastme õpilastest loeb läbi kõik koolikirjanduse teosed, kuid tervelt veerand õpilastest vastas, et nad loevad nii vähe kui võimalik - mõningal juhul isegi mitte ühtegi raamatut (Rebane 2012: 40). Seega - mis on kohustuslik, võib olla hoopis eemalepeletav, seda eriti teismeeas.

\section{Kokkuvõtteks}

Mida võib siis eesti koolinoorte lugemisharjumuste kohta järeldada?

Arvamus, et tänapäeva noor üldse ei loe, ei pea paika. Noorte enamik oskab nimetada kirjanikke ja nende teoseid, neil on omad maitse-eelistused, mida kujundab teatava piirini ka koolikirjandus, ja nad oskavad oma eelistusi nii autorite kui ka teoste osas põhjendada.

Pigem tasub eri uurimustest järeldada, et tähelepanu vajab õpilaste lugemistehnika, mis paneb esimesel kahel kooliastmel aluse lugemisvilumusele ja ilukirjanduse nautimisele. PISA 2009 tõi välja, et 13,3\% Eesti 15-aastastest õpilastest on omandanud lugemise vaid baastasemel (Puksand 2010a: 32; EU High Level Group of Experts on Literacy 2012: 36), mis võimaldab küll lugeda primitiivseid argitekste, kuid ei luba nautida mitmepalgelist ilukirjandust. Kehvale lugemisoskusele viitab ka Liivia Rebase uurimuses $41 \%$ kolmanda kooliastme poiste arvamus, et hea raamat on suurte piltidega ja õhuke, et seda oleks kerge lugeda (Rebane 2012: 42).

Lugemisoskust on eluliselt vaja, kuid sellele pannakse alus eelkõige varases koolieas. Euroopa Komisjoni ekspertide rühm rõhutab vajadust luua kirjaoskuskeskkond (ingl literate environment) juba varases lapseeas ja kaasata lugemise õpetamisse lapsevanemaid (EU High Level Group of Experts on Literacy 2012: 64). Eestis algab selline keskkond eeltoodu järgi kodunt, sellele on lasteaedade ja algklasside kaudu kaasa aidanud Eesti Lugemisühingu projekt „Lugemispesa”, mille raames tehakse koolitusi ka lapsevanematele (vt Eesti Lugemisühing).

Kui lugemisoskus on üldiselt tugevasti seotud ilukirjanduse lugemisega, siis ei maksa seda seost alahinnata. Tõsiselt tuleb mõelda, kuidas luua suhe kirjanduse kui kunstiliigiga. Krista Kerge hoiatab, et „halb kirjandusõpetus võib endale tähtsa tekstistiku avastamissoovi igaveseks pärssida, eduajastu töökoormus lugemisvõimaluse unistuseks jätta ja väsimus madaldada vaimsed nõuded suvalise TV-järjeka lõõgastuse tasemele" (Kerge 2004). Gay Ivey ja Karen Broaddus arvavad, et sageli ei täida kirjandustund oma eesmärki: õpilastelt oodatakse iseseisvaks lugejaks saamist, kuid neile antakse vähe võimalusi uurida neid ennast huvitavat kirjandust, lugeda omas tempos või otsustada, kas lugeda raamat läbi või mitte (Ivey, Broaddus 2001). Samas seab Eestis õpetamisele omad piirid õppekava ja ka ühiskondlik arvamus (vt nt Arrak 2012; Hennoste 2011). 
Oluliseks on muutunud kriitiline lugemisoskus, kuid sageli on õpetajatele ebaselge, kuidas seda saavutada. Ivey ja Broaddus toovad välja, et õpetajad küll tahavad, et õpilased oleksid võimelised kriitiliselt lugema, kuid samas lubavad harva neil algatada vestlusi raamatute üle (Ivey, Broaddus 2001). PISA 2009 taustauuringust aga selgub, et 60 protsendile Eesti õpilastest meeldib väljendada oma arvamust loetud raamatute kohta, ning 35 protsendile meeldib rääkida teiste inimestega raamatutest (Puksand 2012b). Üheks selle põhjuseks võib olla muidugi tõik, et Eesti õpilased on harjunud kirjandustundides oma arvamust avaldama, ning seda tulebki soosida.

Värskelt kehtima hakanud õppekavas (PRÕK 2011, GRÕK 2011) on kirjandus ja eesti keel alates 5. klassist kaks ainet.11 Nii langeb kirjandusele suurem tähelepanu, kuid on ka suurem oht etteantud nimekirjade sisus eksida. Kuigi Andrus Org toob eesti keele ja kirjanduse valdkonnaraamatus välja soovitusliku nimekirja ning soovitab koolilugemise valikul lähtuda õpilaste ja klassi eripärast (Org 2012), siis ometi on õpetajad harjunud kasutama pigem mõistet kohustuslik kirjandus ja pakuvad õpilastele lugemiseks suhteliselt kindla valiku (vt nt Hein 2012). Teisalt peaks igasugused tekstitööoskused olema nüüd paremini tagatud. Peale selle, et kirjandus on eraldi aine, paneb nii põhikooli kui ka gümnaasiumi õppekava ka eesti keele aines rõhku just tekstide mõistmisele ja nende tõlgendamise võimalustele. Ka sunnib gümnaasiumi uut tüüpi eesti keele riigieksam - loomult tekstide analüüsi, seostamise ja loomise eksam - õpetajaid lugemisele rohkem tähelepanu pöörama. Nii on ilukirjandusliku lugemuse püsimiseks loodud hea foon.

Isegi kui vaid väike osa noori ilukirjandust ei loe, vajab tähelepanu, mis on nende huviväljas. Lugemiskohustus on põhjendatud, kuid ei tohi unustada, et lugemiskogemus on sügavalt isiklik. Teema ea- ja ajakohase huvitavuse kõrval tasub veel kord nimetada individuaalset vaimset suhet kindla tekstiga: huvi hoidmiseks on tähtis õige proportsioon lugemiseks vajamineva pingutuse ja sellest tekkiva taipamise/äratundmise vahel (Beaugrande, Dressler 1981). Koolikirjandus toob küll osavad noored lugejad põnevasse ilukirjandusmaailma, kuid raamatud, mis ei ole individuaalselt huvitavad, ea- või jõukohased, peletavad noore sealt hoopis eemale. Individuaalne retseptsioon, isiklik suhe kirjandusega on praegu meie kirjanduse õppekavadesse ja õpivarasse (vt Nootre 2004) sisse kirjutatud, kuid teema väärib siiski püsivat eritähelepanu, sest harjumuste ja arusaamiste muutmine koolis on aeganõudev protsess.

Artikkel on valminud Eesti Teadusfondi grandi 8605 toel.

\section{Kirjandus}

A r r a k, Andres 2012. Emakeele(tuse)st. - Postimees 14. III 2012.

B e a u g r a n d e, Robert-Alain de, D r e s s le r, Wolfgang Ulrich 1981. Research and Schooling. - Robert-Alain de Beaugrande, Wolfgang Ulrich Dressler, Introduction to Text Linguistics. London-New York: Longman = [Digitalized version] 2002. http://www.beaugrande.com/introduction_to_text_linguistics.htm (22. V 2012).

${ }^{11} \mathrm{Vt}$ ainekavu viidatud õppekavade lisades elektroonilisest Riigi Teatajast või õppekavade kodulehelt www.oppekava.ee. 
B l o o r, Meriel 2004. Towards a systemic functional model for comparing forms of discourse in academic writing. - Ilha do Desterro. Journal of English Language, Literatures in English and Cultural Studies. Revista de Língua Inglesa, Literaturas em Inglês e Estudos Culturais. Kd 46 (Special Issue on Systemic Functional Linguistics in Action), lk 83-115.

Considine, David, Horton, Julie, M o or m a n, Gary 2009. Teaching and reading the millennial generation through media literacy. - Journal of Adolescent \& Adult Literacy, kd 52 (6), lk 471-481.

EU High Level Group of Experts on Literacy 2012. Final Report. European Commission. http://ec.europa.eu/education/literacy/what-eu/high-level-group/documents/literacy-report.pdf

G a r b e, Christine, H o lle, Karl, We in h o ld, Svantje (toim) 2010. ADORE Teaching Struggling Adolescent Readers in European Countries. Frankfurt am Main-Berlin-Bern-Bruxelles-New York-Oxford-Wien: Peter Lang.

Griffith, Pricilla E., R u n, Jiening 2005. What is metacognition and what sould be its role in literacy instruction? - Metacognition in Literacy Learning. Theory, Assessment, Instruction, and Professional Development. Toim Susan E. Israel, Cathy Collins Block, Kathryn L. Bauserman, Kathryn KinnucanWelsch. Mahwah (NJ)-London: Lawrence Erlbaum, lk 3-18.

GRÕK 2011 = Gümnaasiumi riiklik õppekava. - Elektrooniline Riigi Teataja. https://www.riigiteataja.ee/akt/114012011002 (25. V 2012).

H e i n, Ivika [2012]. Õpetaja töökava. Näidistöökava 7. klassile. - http://www. oppekava.ee/ $\rightarrow$ Põhikooli valdkonnaraamatud ja valikainete aineraamatud $\rightarrow$ Ainevaldkond „Eesti keel ja kirjandus” $\rightarrow$ Kirjandus. III kooliaste. (25. VI 2012.)

He n n o s te, Tiit 2011. Vastuolude aeg. - Sirp 16. IX.

$\mathrm{H}$ o p p e r, Rosemary 2005 . What are teenagers reading? Adolescent fiction reading habits and reading choices. - Literacy, kd 39 (3), lk 113-120.

I ve y, Gay, B r o a d d u s, Karen 2001. „Just plain reading”: A survey of what makes students want to read in middle school classrooms. - Reading Research Quarterly, kd 36 (4), lk 350-377.

J ärve, Malle 1993. The reception of literature in Estonia. Favourite books and the case of Tammsaare. - The Cultural Study of Reception. (Nykykulttuurin tutkimusyksikön julkaisuja 38.) Jyväskylä: The University of Jyväskylä, lk 43-50.

K e r g e, Krista 2003. Eesti kirjakeele mõtteruum. - Emakeele Seltsi aastaraamat 49 (2003). Tallinn: Emakeele Selts, lk 7-22.

Ke r g e, Krista 2004. Koolikirjandus läbi värske maasoolase vaatepilgu. - Eesti Päevaleht 22. X 2004.

Kr u u s, Priit 2010. Noored ja kirjandus. - Keel ja Kirjandus, nr 12, lk 928-930.

L i n n a k y l ä, Pirjo 2008. Wie kann man Schüler und Schülerinnen für das Lesen motivieren? - Checkpoint Literacy. Toim B. Hoffmann, R. Valtin. Berlin: DGLS, lk 20-39.

L u h a r i, Bärbel, S õ r m u s, Ester 2001. Õpilane, raamat, raamatukogu. Uurimused õpilaste lugemisest ja õppekava toetavast kirjandusest kooliraamatukogudes. Tallinn: Eesti Raamatukoguhoidjate Ühing.

M i a 1 l, David S. 2006. Literary Reading: Empirical and Theoretical Studies. New York-Bern-Berlin-Bruxelles-Frankfurt am Main-Oxford-Wien: Peter Lang.

N o o tr e, Sirje 2004. Kirjanduse kõnetus. Gümnaasiumiõpik. Tallinn: Avita.

OECD 2010 = PISA 2009 Results: Learning to Learn - Student Engagement, Strategies and Practices (Kd III). OECD. 
O r g, Andrus [2012]. Autorite ja teoste valikust ning käsitlemisest III kooliastmes. - http://www.oppekava.ee/ $\rightarrow$ Põhikooli valdkonnaraamatud ja valikainete aineraamatud $\rightarrow$ Ainevaldkond „Eesti keel ja kirjandus” $\rightarrow$ Kirjandus. III kooliaste. (25. VI 2012.)

Peri e, Marianne, M or a n, Rebecca, Lutku s, Anthony D. 2005. NAEP 2004 trends in academic progress: Three decades of student performance in reading and mathematics (NCES Publication No. 2005-464). Washington, DC: National Center for Education Statistics, Institute of Education Sciences, U.S. Department of Education.

PRÕK 2011 = Põhikooli riiklik õppekava. - Elektrooniline Riigi Teataja. https:// www.riigiteataja.ee/akt/13273133 (25. V 2012).

[P u k s a n d, Helin] 2010a. Lugemine. Lugemis- ja õppimisharjumused 15-aastastel õpilastel. - Gunda Tire, Helin Puksand, Imbi Henno, Tiit Lepmann. PISA 2009 - Eesti tulemused. Eesti 15-aastaste õpilaste teadmised ja oskused funktsionaalses lugemises, matemaatikas ja loodusteadustes. Tallinn: Haridus- ja Teadusministeerium, lk 21-74.

P u k s a n d, Helin 2010b. Tekstid, mida loevad teismelised. Teismeliste lugemisharjumuste kasutamine koolis. - Tekstiuurimus ja kool. (Tekstid ja taustad 6 . Emakeeleõpetuse Infokeskuse toimetised 5.) Toim Krista Kerge. Tallinn: Tallinna Ülikooli Kirjastus, lk 20-35.

Puks a nd, Helin 2011. Eesti koolinoorte lugemisharjumused meedia näitel. Eesti Rakenduslingvistika Ühingu aastaraamat 7. Tallinn, lk 179-195.

Puks and, Helin [2012a]. Eesti õpilaste lugemisharjumustest. - http://www. oppekava.ee/ $\rightarrow$ Gümnaasiumi valdkonnaraamatud ja valikainete aineraamatud $\rightarrow$ Valdkonnaüleseid käsitlusi. (25. V 2012.)

P u ks a n d, Helin 2012b (ilmumas). Reading habits of the Estonian adolescents - the basis for lifelong learning. - Lifelong Learning and Teacher Development. (Estonian Studies in Education 4.) Toim Jaan Mikk, Piret Luik, Marika Veisson. Frankfurt am Main: Peter Lang.

P u k s a n d, Helin, K e r g e, Krista 2012. Õpiteksti analüüs kirjaoskuse omandamise kontekstis. - Emakeele Seltsi aastaraamat 57 (2011). Tallinn: Emakeele Selts, lk 162-217.

$\mathrm{R}$ e b a n e, Liivia 2012. Teise ja kolmanda kooliastme õpilaste lugemisharjumused ja neid mõjutavad tegurid. Magistritöö. Tartu: Tartu Ülikool. http://www. murre.ut.ee/arhiiv/naita_pilt.php?materjal=kasikiri\&materjal_id=D1747\&sari=D (10. IX 2012).

S c h u n k, Dale H., P in tri c h, Paul R., M e e c e, Judith 2009. Motivation in Education: Theory, Research, and Applications. Upper Saddle River, NJ: Pearson/ Merrill Prentice Hall.

S u lk u n e n, Sari, A rffm a n, Inga 2010. Key element No 4: Choosing engaging reading materials. - Christine Garbe, Karl Holle, Svantje Weinhold, ADORE Teaching Struggling Adolescent Readers in European Countries. Frankfurt am Main-Berlin-Bern-Bruxelles-New York-Oxford-Wien: Peter Lang, lk 102-113.

T a m m e mä e, Tiiu 2009. Kahe- ja kolmeaastaste eesti laste kõne arengu tase Revnelli ja HYKS testi põhjal ning selle seosed koduse kasvukeskkonna teguritega. (Tallinna Ülikooli sotsiaalteaduste dissertatsioonid.) Tallinn: Tallinna Ülikooli Kirjastus.

Välijärvi, Jouni, Li n n a ky lä, Pirjo (toim) 2002. Tulevaisuuden osaajat. PISA 2000 Suomessa. Helsinki: Koulutuksen tutkimuslaitos. Opetushallitus. OECD. 


\section{Võrgumaterjal}

Eesti Kirjastuste Liit. http://www.estbook.com/index.php?id=1 (28. V 2012).

Eesti Lugemisühing. http://www.lugemisyhing.ee (28. V 2012).

Nukitsa konkurss. Eesti Lastekirjanduse Keskus. http://www.eltk.ee/keskusetegevus/nukitsa-konkurss (30. V 2012).

Tartu Linnaraamatukogu kirjandusveeb. Edetabelid. http://www.luts.ee/lugemissoovitus/index.php?option=com_content\&view=category\&id=44\&Itemid=64 $(15$. VIII 2012).

Varraku raamatublogi. http://blog.varrak.ee/ (4. VI 2012).

\section{The Reading Habits of Estonian Schoolchildren}

Keywords: reading competence, reading experience, school literature, favourite book, literature teaching

In the rapidly changing world of today many adults have gained an impression that young people are sitting in front of a computer rather than reading fiction. Nevertheless, according to a study carried out in Estonia in 2008-2009 most of the schoolchildren can name their favourite authors as well as books, giving reasonable arguments for their choice. Literature lessons have a significant role in shaping pupils' taste in literature, as many a good book would otherwise miss their attention. However, in drawing up the lists of school literature, more attention should be paid to the age and abilities of the audience as poor reading competence combined with a restive mind is hardly enabling enjoyment of a rich text of fiction, rather, it may scare children off the literary world.

Helin Puksand (b. 1970), Tallinn University, Institute of Educational Sciences, doctoral student, lecturer in School Pedagogy, helinp@tlu.ee 